\title{
Root Formation in Cuttings of English Ivy Treated with Paclobutrazol or Uniconazole
}

\section{R.L. Geneve \\ Department of Horticulture and Landscape Architecture, University of Kentucky, Lexington, KY 40546}

Additional index words. NAA, naphthaleneacetic acid, Hedera helix, root initiation

Adventitious root initiation in cuttings can be stimulated by auxin, but, in difficult-toroot species, auxin generally fails to promote rooting. Several triazole compounds have demonstrated growth regulator properties and have been introduced as growth retardants affecting stem elongation (Wample and Culver, 1983). These growth effects have been associated with inhibition of gibberellic acid biosynthesis (Rademacher et al., 1984). Low concentrations of triazole growth retardants, such as paclobutrazol, uniconazole, and triadimefon, have stimulated root formation in easy-to-root species (Davis et al., 1985, 1986; Fletcher et al., 1988), but, to the best of our knowledge, have not been evaluated on difficult-to-root species. The objective of this study was to compare the effect of triazole growth retardants on the easy-to-root juvenile and the difficult-to-root mature phases of English ivy (Hedera helix L.) using a debladed petiole rooting assay.

The English ivy debladed petiole rooting assay was used following the procedures of Geneve et al. (1988). Fully expanded leaf blades and petioles were collected from stock plants of juvenile- and mature-phase English ivy grown under greenhouse conditions $(\mathrm{Ge}-$ neve et al., 1988). The lamina was removed from the petiole and the petiole was surface sterilized for $10 \mathrm{~min}$ in a $0.5 \% \mathrm{NaOCl}$ plus $0.1 \%$ Alconox detergent solution. The petioles were rinsed three times in sterile, deionized water and $2.3-\mathrm{cm}$ explants were prepared aseptically. Each replication consisted of five petioles cultured in a $25-\mathrm{ml}$ Erlenmeyer flask containing $1 \mathrm{ml}$ of a modified Romberger medium plus the test compound. Cultures were maintained in a growth chamber at $25 \pm 2 \mathrm{C}$ with a 16-hr photoperiod with $100 \mu \mathrm{mol} \cdot \mathrm{s}^{-1} \cdot \mathrm{m}^{-2}$ photosynthetic photon flux provided by cool-white fluorescent lamps. Compounds tested were NAA $(0,30$, and $100 \mu \mathrm{M})$ alone or in combination

Received for publication 24 Apr. 1989. Kentucky Expt. Sta. Journal Article 89-10-19. The cost of publishing this paper was defrayed in part by the payment of page charges. Under postal regulations, this paper therefore must be hereby marked advertisement solely to indicate this fact. with paclobutrazol or uniconazole $(1 \mu \mathrm{M})$. Visible roots were counted after 18 days. The experiments were arranged in a completely randomized design with subsampling $(\mathrm{n}=30)$. Each experiment was repeated at least twice and the results presented were from representative experiments.

Four-node terminal stem cuttings were also taken from the same stock plants as petiole explants. Twenty-five cuttings were placed in 250-ml beakers containing $100 \mathrm{ml}$ of deionized water or $50 \mu \mathrm{M}$ aqueous paclobutrazol solution. After $24 \mathrm{hr}$, juvenile and mature cuttings absorbed an average of 1.6 and $1.4 \mathrm{ml}$ of solution per cutting, respectively. Cuttings were inserted into $50 \times 35$ $\times 10-\mathrm{cm}$ plastic flats containing a rooting medium of 1 perlite : 1 vermiculite $(\mathrm{v} / \mathrm{v})$. Cuttings were rooted in the greenhouse under intermittent mist with bottom heat (27C). The cuttings were arranged in the cutting flat in a completely randomized block design ( $\mathrm{n}$ $=50$ ) and number of roots per cutting was counted at 30 and 50 days after treatment.

Paclobutrazol and uniconazole promoted root formation in auxin-treated juvenile debladed petiole cuttings (Table 1). These re-

Table 1. Mean number of roots in debladed petiole cuttings of juvenile English ivy treated with $1 \mu \mathrm{M}$ paclobutrazol or uniconazole. ${ }^{2}$

\begin{tabular}{rccc}
\hline \hline \multirow{2}{*}{$\begin{array}{c}\text { NAA } \\
(\mu \mathrm{M})\end{array}$} & Control & \multicolumn{2}{c}{ Growth retardant ${ }^{\mathrm{y}}$} \\
\cline { 3 - 4 } & Paclobutrazol & Uniconazole \\
\hline 0 & 0 & -0 & 0 \\
30 & $2.6 \pm 0.6$ & $5.6 \pm 0.7$ & $5.3 \pm 0.9$ \\
100 & $7.3 \pm 0.5$ & $10.0 \pm 0.9$ & $9.5 \pm 0.9$ \\
\hline
\end{tabular}

${ }^{\mathrm{z}}$ Mature-phase cuttings failed to root, regardless of NAA or growth retardant treatment.

'Mean number of roots $\pm 95 \%$ confidence interval.

Table 2. Adventitious root formation in juvenile- and mature-phase stem cuttings of English ivy pretreated for $24 \mathrm{hr}$ with 0 or $50 \mu \mathrm{m}$ paclobutrazol and evaluated 30 and 50 days after treatment.

\begin{tabular}{llllll}
\hline \hline & \multicolumn{4}{c}{ Mean no. roots/cutting } \\
\cline { 2 - 6 } Treatments & \multicolumn{2}{c}{ At 30 days } & \multicolumn{2}{c}{ At 50 days } \\
\cline { 2 - 3 } \cline { 2 - 3 } & Juvenile & Mature & & Juvenile & Mature \\
\hline Control & $25.8 \pm 2.3^{\mathrm{z}}$ & $5.3 \pm 1.7$ & & $30.4 \pm 2.8$ & $21.7 \pm 3.3$ \\
Paclobutrazol & $56.9 \pm 4.8$ & $4.4 \pm 1.4$ & & $89.8 \pm 7.6$ & $16.6 \pm 3.1$ \\
\hline
\end{tabular}

${ }^{2}$ Mean number of roots $\pm 95 \%$ confidence interval. suits support work with other easy-to-root species, where pretreatment with triazole inhibitors promoted root formation (Davis et al., 1985, 1986; Fletcher et al., 1988). However, the difficult-to-root mature-phase petiole cuttings of English ivy failed to root, regardless of treatment. Pretreatment with paclobutrazol significantly promoted rooting in juvenile stem cuttings (Table 2). This supports the results from the debladed petiole rooting assay. However, there was no promotive effect on root formation in mature stem cuttings. Hackett (1970), investigating rooting cofactors extracted from the juvenile phase of English ivy, emphasized that results obtained in studies using only easy-to-root species may not have direct application to difficult-to-root cuttings, even of the same clone. It is clear from this study that the promotive effects of triazole growth retardants were limited to the easy-to-root juvenile phase of English ivy. These results suggest that including triazole growth retardants in a rooting program may not be beneficial where ontogenetic age is a limiting factor for 'a difficult-to-root species.

\section{Literature Cited}

Davis, T. D., N. Sankhla, R.H. Waker, and A. Upadhyaya. 1985. Promotion of adventitious root formation on cuttings by paclobutrazol. HortScience 20:883-884.

Davis, T. D., R.H. Walser, K. Soerenson, and N. Sankhla. 1986. Rooting and subsequent growth of cuttings treated with paclobutrazol. Plant Prop. 32(1):7-9.

Fletcher, R. A., N.K. Asare-Boamah, L.C. Krieg, G. Hofstra, and E.B. Dumbroff. 1988. Triadimefon stimulates rooting in bean hypocotyl. Physiol. Plant. 73:401-405.

Geneve, R. L., W.P. Hackett, and B.T. Swanson. 1988. Adventitious root initiation in de-bladed petioles from the juvenile and mature phase of English ivy. J. Amer. Soc. Hort. Sci. 113:630635.

Hackett, W.P. 1970. The influence of auxin, catechol and methanolic tissue extracts on root initiation in aseptically cultured shoot apices of the juvenile and adult forms of Hedera helix. J. Amer. Soc. Hort. Sci. 95:398-402.

Rademacher, W., J. Jung, J.E. Graebe, and L. Schwenen. 1984. On the mode of action of tetcyclasis and triazole growth retardants. Brit. Plant Growth Regulator Group Monogr. 11:1-11.

Wample, R.L. and E.B. Culver. 1983. The influence of paclobutrazol, a new growth regulator, on sunflowers. J. Amer. Soc. Hort. Sci. 108:122-125. 